\title{
Combination bronchodilator therapy in the management of chronic obstructive pulmonary disease
}

\author{
Donald P Tashkin ${ }^{1 *}$ and Gary T Ferguson ${ }^{2}$
}

\begin{abstract}
Chronic obstructive pulmonary disease (COPD) represents a significant cause of global morbidity and mortality, with a substantial economic impact. Recent changes in the Global initiative for chronic Obstructive Lung Disease (GOLD) guidance refined the classification of patients for treatment using a combination of spirometry, assessment of symptoms, and/or frequency of exacerbations. The aim of treatment remains to reduce existing symptoms while decreasing the risk of future adverse health events. Long-acting bronchodilators are the mainstay of therapy due to their proven efficacy. GOLD guidelines recommend combining long-acting bronchodilators with differing mechanisms of action if the control of COPD is insufficient with monotherapy, and recent years have seen growing interest in the additional benefits that combination of long-acting muscarinic antagonists (LAMAs), typified by tiotropium, with long-acting $\beta_{2}$-agonists ( $\left.L A B A s\right)$, such as formoterol and salmeterol. Most studies have examined free combinations of currently available LAMAs and LABAs, broadly showing a benefit in terms of lung function and other patient-reported outcomes, although evidence is limited at present. Several once- or twice-daily fixed-dose LAMA/LABA combinations are under development, most involving newly developed monotherapy components. This review outlines the existing data for LAMA/LABA combinations in the treatment of COPD, summarizes the ongoing trials, and considers the evidence required to inform the role of LAMA/LABA combinations in treatment of this disease.
\end{abstract}

Keywords: COPD, Combination therapy, Bronchodilation, Beta 2 agonist, Antimuscarinic

\section{Introduction}

Currently the fourth leading cause of death globally [1], chronic obstructive pulmonary disease (COPD) is a major cause of morbidity and mortality, projected to become the world's third leading cause of mortality by 2020 [2]. Characterized by progressive airflow limitation, COPD also has a major economic impact, contributing to US\$53.7 billion in related direct costs in 2008 in the US [3].

As an area of interest for physicians, and a logical progression from monotherapy for those seeking to further improve outcomes in patients with respiratory disease, the subject of combined bronchodilation with bronchodilators of differing modes of action has been discussed in the literature previously [4-8]. The aim of this review is to focus more specifically on the combination of long-

\footnotetext{
* Correspondence: DTashkin@mednet.ucla.edu

'Department of Medicine, David Geffen School of Medicine at UCLA, 405 Hilgard Avenue, Los Angeles, CA 90095, USA

Full list of author information is available at the end of the article
}

acting muscarinic antagonists (LAMAs) and long-acting $\beta_{2}$-agonists (LABAs) for the treatment of COPD, summarizing data from recent peer-reviewed publications and published abstracts.

\section{Evolving COPD guidelines}

2011 saw a substantial revision of the Global initiative for chronic Obstructive Lung Disease (GOLD) guidelines for diagnosis, management, and prevention of COPD, which has recently been updated [9]. Recommendations for treatment are no longer based primarily on categorization ("staging") by spirometric assessment, but on categorization by existing symptoms (using validated modified Medical Research Council and COPD Assessment Test questionnaires) and risk (based on severity of airflow limitation and history of exacerbations). This approach acknowledges the importance of consideration of both short- and long-term outcomes when making treatment decisions (Figure 1) [9].

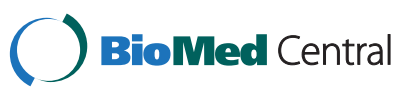

(c) 2013 Tashkin and Ferguson; licensee BioMed Central Ltd. This is an Open Access article distributed under the terms of the Creative Commons Attribution License (http://creativecommons.org/licenses/by/2.0), which permits unrestricted use,

distribution, and reproduction in any medium, provided the original work is properly cited. 


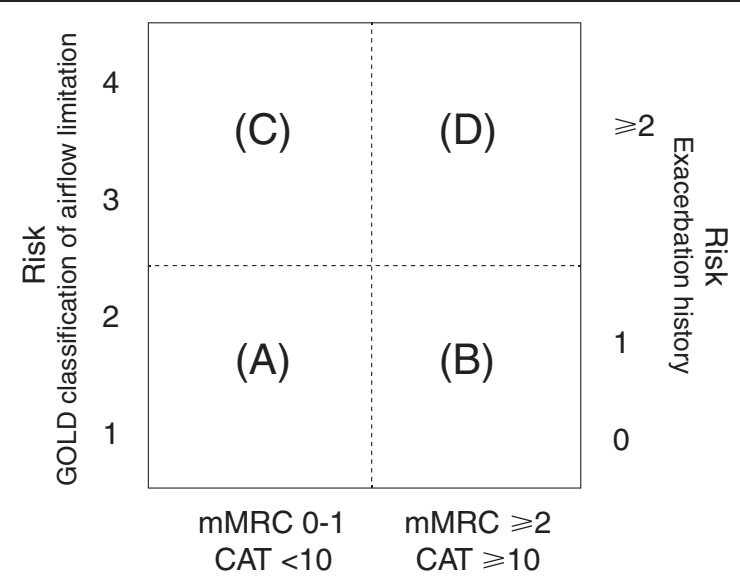

Symptoms

(mMRC or CAT score)

\begin{tabular}{cccccc}
\hline $\begin{array}{c}\text { Patient } \\
\text { category }\end{array}$ & Characteristics & $\begin{array}{c}\text { Spirometric } \\
\text { classification }\end{array}$ & $\begin{array}{c}\text { Exacerbations } \\
\text { per year }\end{array}$ & mMRC & CAT \\
\hline A & Low risk: less symptoms & GOLD 1-2 & $\leqslant 1$ & $0-1$ & $<10$ \\
B & Low risk: more symptoms & GOLD 1-2 & $\leqslant 1$ & $\geqslant 2$ & $\geqslant 10$ \\
C & High risk: less symptoms & GOLD 3-4 & $\geqslant 2$ & $0-1$ & $<10$ \\
D & High risk: more symptoms & GOLD 3-4 & $\geqslant 2$ & $\geqslant 2$ & $\geqslant 10$ \\
\hline
\end{tabular}

Figure 1 Model of symptom/risk of evaluation of COPD [9]. From the Global Strategy for Diagnosis, Management and Prevention of COPD 2013, Global initiative for chronic Obstructive Lung Disease (GOLD), http://www.goldcopd.org. COPD = chronic obstructive lung disease; $\mathrm{GOLD}=$ Global initiative for chronic Obstructive Lung Disease; mMRC = modified Medical Research Council; CAT = COPD Assessment Test.

\section{Long-acting bronchodilators: the cornerstone of COPD maintenance therapy}

Two key classes of bronchodilators have been developed in COPD: $\beta_{2}$-agonists and muscarinic antagonists. Shortacting bronchodilators, such as ipratropium, albuterol, and metaproterenol, have formed the cornerstone of initial COPD therapy for the past two decades $[9,10]$. Subsequently, long-acting bronchodilators were developed. The twice-daily LABAs salmeterol and formoterol first became available for maintenance therapy of COPD more than 15 years ago, while the once-daily LAMA tiotropium has been available for 10 years and is the most widely prescribed maintenance monotherapy bronchodilator in COPD [11]. Inhaled bronchodilators, as monotherapy or in combination, remain the mainstay for patients in all categories (Table 1) [9]. Long-acting bronchodilators, such as tiotropium, formoterol, and salmeterol, are proven to provide long-term improvements in lung function, quality of life, and exacerbations in patients with COPD [12-14]. Long-acting bronchodilators (e.g., tiotropium, salmeterol) also reduce lung hyperinflation and dyspnea, and increase exercise endurance [15,16], although a recent review suggested further data are required on the benefits of longacting bronchodilators on exercise tolerance [17]. There are a variety of long-acting bronchodilators available (Table 2) [18-34]. The once-daily LABA indacaterol, the once-daily LAMA glycopyrronium, and twice-daily LAMA aclidinium represent newer, recently licensed therapies, and there are also several once-daily LABAs and LAMAs in development, including olodaterol, vilanterol, and glycopyrrolate (Table 2).

\section{Combination bronchodilation: rationale}

Guidelines recommend combination therapy involving two long-acting bronchodilators with differing modes of action in patients whose COPD is not sufficiently controlled with monotherapy (Table 1) [9]. The mechanistic rationale for combination of a muscarinic antagonist and a $\beta_{2}$-agonist has been reviewed in detail recently [35,36]; as such, we will only briefly discuss it here. Airway smooth muscle relaxation (leading to bronchodilation) can be achieved via two main routes: inhibition of acetylcholine signaling via muscarinic $M_{3}$ receptors on airway smooth muscle with a muscarinic antagonist, or stimulation of $\beta_{2}$-adrenoceptors with a $\beta_{2}$-agonist [35,36]. Targeting these two mechanisms of bronchoconstriction, theoretically, has the potential to maximize the bronchodilator response without increasing the dose of either component, and helps to overcome the inter- and intra-patient variability in response to individual agents seen in COPD [35]. The interaction between the two systems has yet to be fully elucidated; however, $\beta_{2}$-agonists can amplify the 
Table 1 GOLD guidelines (2013): pharmacologic therapies for stable COPD ${ }^{\mathrm{a}}$ [9]

\begin{tabular}{|c|c|c|c|}
\hline Patient group & 1st choice & 2nd choice & Alternative \\
\hline A: GOLD 1-2 & \multirow{2}{*}{$\begin{array}{c}\text { Short-acting anticholinergic } \\
\text { prn OR SABA prn }\end{array}$} & \multirow{2}{*}{$\begin{array}{l}\text { LAMA OR LABA OR SABA and } \\
\text { short-acting anticholinergic }\end{array}$} & \multirow[t]{2}{*}{ Theophylline } \\
\hline Low risk of exacerbation, less symptoms & & & \\
\hline B: GOLD 1-2 & \multirow[t]{2}{*}{ LAMA OR LABA } & \multirow[t]{2}{*}{ LAMA and LABA } & $\begin{array}{l}\text { SABA and/or short-acting } \\
\text { anticholinergic }\end{array}$ \\
\hline Low risk of exacerbation, more symptoms & & & Theophylline \\
\hline C: GOLD 3-4 & \multirow[t]{2}{*}{$I C S+L A B A$ OR LAMA } & \multirow[t]{2}{*}{$\begin{array}{l}\text { LAMA and LABA OR LAMA and PDE-4 inhibitor } \\
\text { OR LABA and PDE-4 inhibitor }\end{array}$} & $\begin{array}{l}\text { SABA and/or short-acting } \\
\text { anticholinergic }\end{array}$ \\
\hline High risk of exacerbation, less symptoms & & & Theophylline \\
\hline D: GOLD 3-4 & \multirow[t]{3}{*}{$I C S+L A B A$ and/or LAMA } & \multirow{3}{*}{$\begin{array}{c}\text { ICS and LABA and LAMA } \\
\text { OR ICS + LABA and PDE-4 inhibitor } \\
\text { OR LAMA and LABA } \\
\text { OR LAMA and PDE-4 inhibitor }\end{array}$} & Carbocysteine \\
\hline \multirow[t]{2}{*}{ High risk of exacerbation, more symptoms } & & & $\begin{array}{l}\text { SABA and/or short-acting } \\
\text { anticholinergic }\end{array}$ \\
\hline & & & Theophylline \\
\hline
\end{tabular}

From the Global Strategy for Diagnosis, Management and Prevention of COPD 2013, Global initiative for chronic Obstructive Lung Disease (GOLD), http://www.goldcopd.org.

${ }^{a}$ Medications in each box are mentioned in alphabetical order, and, therefore, not necessarily in order of preference.

prn = as needed; SABA = short-acting $\beta_{2}$-agonist; LABA = long-acting $\beta_{2}$-agonist, LAMA = laong-acting muscrannic antagonist; ICS = inhaled corticosteroid;

$\mathrm{PDE}=$ phosphodiesterase

bronchial smooth muscle relaxation directly induced by the muscarinic antagonist by decreasing the release of acetylcholine via modulation of cholinergic neurotransmission. Additionally, muscarinic antagonists have been demonstrated to augment $\beta_{2}$-agonist-stimulated bronchodilation by reducing the bronchoconstrictor effects of acetylcholine in preclinical models [35].

The rationale for improved bronchodilation has been tested in preclinical models with a specific investigational
LAMA/LABA combination, tiotropium plus olodaterol, demonstrating synergistic effects on bronchoprotection in vivo $[37,38]$. Combination treatment in ovalbumininduced bronchoconstriction in anesthetized guinea pigs has demonstrated improved bronchoprotection in a dosedependent manner, with effective dose (ED) 50 values 10 -fold lower than the ED50 of olodaterol alone $(\mathrm{p}<0.05)$ [38]; similar results were reported versus tiotropium monotherapy in acetylcholine-induced bronchoconstric-

Table 2 LABAs and LAMAs in development for combination therapies

\begin{tabular}{|c|c|c|c|c|c|}
\hline Therapy & $\begin{array}{l}\text { LABA/ } \\
\text { LAMA }\end{array}$ & Manufacturer & Dosage & Time to onset & $\begin{array}{c}\text { Trough } \mathrm{FEV}_{1} \\
\text { (difference from placebo) }\end{array}$ \\
\hline \multirow[t]{2}{*}{ Formoterol } & LABA & Merck $^{a}$ & Twice daily & $5 \min [26]$ & $50-90 \mathrm{~mL}[26]$ \\
\hline & & & $4.5 \mu \mathrm{g}(\mathrm{MDI})$ and $12 \mu \mathrm{g}(\mathrm{DPI})$ & & \\
\hline Indacaterol & LABA & Novartis & Once daily 150 and 300 mg (EU) (DPI) [20] & $5 \min [22]$ & $130-180 \mathrm{~mL}(p<0.001)[22]$ \\
\hline Indacaterol & LABA & Novartis & Once daily $75 \mu \mathrm{g}$ (US) (DPI) [21] & $5 \min [22]$ & $\geq 120 \mathrm{~mL}(p<0.001)[23,33]$ \\
\hline Olodaterol & LABA & $\begin{array}{l}\text { Boehringer } \\
\text { Ingelheim }\end{array}$ & Once daily 5 and $10 \mu \mathrm{g}$ (Respimat ${ }^{\oplus}$ ) & Not available & $61-132 \mathrm{~mL}(p<0.01)[24]$ \\
\hline Vilanterol & LABA & GSK & Once daily 25 and $50 \mu \mathrm{g}$ (DPI) & Median 6 min [25] & $137-165 \mathrm{~mL}(p<0.001)[25]$ \\
\hline Aclidinium & LAMA & $\begin{array}{l}\text { Almirall/Forest } \\
\text { Laboratories }\end{array}$ & Twice daily $200-400 \mu \mathrm{g}$ (DPI) & $10-30 \min [27,28]$ & 86-124 mL $(p<0.0001)[29]$ \\
\hline Glycopyrronium & LAMA & Novartis & Once daily 50 mg (DPI) & $5 \min [19,34]$ & $91-108$ mL $(p<0.001)[30,34]$ \\
\hline Glycopyrrolate & LAMA & $\begin{array}{c}\text { Pearl } \\
\text { Therapeutics }\end{array}$ & Twice daily 36 mg (MDI) & $5 \min [19]$ & $\begin{array}{l}\text { Statistically superior to placebo } \\
\qquad(p<0.0001)[31]\end{array}$ \\
\hline GSK233705 & LAMA & GSK & Twice daily $200 \mu \mathrm{g}$ & Not available & $130 \mathrm{~mL}(\mathrm{p}<0.001)[32]$ \\
\hline Tiotropium & LAMA & $\begin{array}{l}\text { Boehringer } \\
\text { Ingelheim }\end{array}$ & Once daily $18 \mu \mathrm{g}(\mathrm{DPI})$ and $5 \mu \mathrm{g}$ (via SMI) & $15 \min [18]$ & $120-150 \mathrm{~mL}(p<0.001)[18]$ \\
\hline Umeclidinium (GSK573719) & LAMA & GSK & Once daily & Not available & Not available \\
\hline
\end{tabular}

${ }^{\mathrm{a}}$ Other companies are developing formoterol as part of a fixed-dose combination.

PubMed and European Respiratory Society and American Thoracic Society congresses were searched for abstracts relating to LAMA/LABA therapies known to be in development as part of a combination. As trials were carried out in different patient populations and there were differences in background medications allowed/utilized, no direct comparisons can be made.

$\mathrm{DPI}=$ dry powder inhaler; $\mathrm{LABA}=$ long-acting $\beta_{2}$-agonist; $\mathrm{LAMA}=$ long-acting muscarinic antagonist; $\mathrm{MDI}=$ metered dose inhaler; SMI $=$ Soft Mist ${ }^{\mathrm{TM}}$ Inhaler. 
tion in anesthetized dogs [37]. Indacaterol synergistically potentiates the effects of glycopyrronium to inhibit metacholine-induced contraction of airway smooth muscle in vitro [39]. However, specifically designed clinical studies are required to assess whether such synergistic effects can be observed with therapeutic doses in humans.

\section{Combination bronchodilation: existing evidence and ongoing studies}

Short-acting muscarinic antagonist plus short-acting $\beta_{2}$-agonist

The concept of adding a muscarinic antagonist to a $\beta_{2}$ agonist is by no means new. A fixed-dose combination (FDC) of the short-acting agents ipratropium and albuterol $\left(\right.$ Combivent $\left.^{\odot}\right)$ and of fenoterol and ipratropium (Berodual ${ }^{\odot}$ ) clearly provides benefits over monotherapy with either component [40-42]. Additionally, dual bronchodilation with ipratropium and albuterol resulted in a consistently longer response and more patients achieved a pre-specified response level (12-15\%) in forced expiratory volume in 1 second $\left(\mathrm{FEV}_{1}\right)$ with the combination versus individual components $(\mathrm{p}<0.05)[40,41,43-45]$, with an equivalent or improved safety profile.

\section{Free combinations of LAMA plus LABA}

Relatively few studies have examined the combination of LAMAs and LABAs. Until recently, research focused on free combinations of existing therapies, and has demonstrated benefits on lung function and other outcomes (Table 3) [46-69].

Following proof of concept in terms of a benefit on $\mathrm{FEV}_{1}$ and in patients with acute exacerbations [70-72], several randomized controlled trials have reported improved lung function for tiotropium plus formoterol versus tiotropium alone [54-56,60,65,73]. Some trials have also identified significant improvements in symptom scores $[55,56,60]$ and reductions in rescue medication use $[47,49,55,56,65]$. A recent meta-analysis confirmed the benefits of tiotropium plus formoterol on average $\mathrm{FEV}_{1}$, trough $\mathrm{FEV}_{1}$, and Transition Dyspnea Index (TDI) [74] (Table 3), with initial reports also suggesting that the combination may provide statistically significant improvements in effort-induced dynamic hyperinflation and exercise tolerance [75].

Currently available data on tiotropium plus salmeterol are conflicting. Initial investigations indicated the benefits of tiotropium plus salmeterol versus either monotherapy alone, while suggesting co-administration of once-daily salmeterol plus tiotropium was inadvisable, due to the shorter duration of bronchodilation provided by salmeterol [76]. The Canadian Optimal Therapy of COPD trial investigated the impact of tiotropium plus placebo, tiotropium plus salmeterol, or tiotropium plus salmeterol/fluticasone on clinical outcomes in
449 patients with moderate to severe COPD [48]. Tiotropium plus salmeterol/fluticasone (but not tiotropium plus salmeterol) statistically improved lung function and quality of life, and, while no improvement in overall exacerbation rate was seen, reduced the number of hospitalizations for exacerbations compared to tiotropium plus placebo [48] (Table 3). A more recent study, however, demonstrated significant improvements in $\mathrm{FEV}_{1}$ with salmeterol once or twice daily plus tiotropium [59], and the combination was also associated with clinically significant improvements in TDI (Table 3). These inconclusive data suggest that further research is necessary to determine any advantage of salmeterol plus tiotropium. Initial investigation of other free combinations has also been reported (Table 3); tiotropium plus indacaterol has been demonstrated to improve lung function and inspiratory capacity, as well as providing a further reduction in use of rescue medication [50]. The LAMA GSK233705 twice daily plus salmeterol has also demonstrated significantly improved trough $\mathrm{FEV}_{1}$ from baseline compared to monotherapy [61]. Overall, these data broadly confirm that combination therapy has the potential to improve outcomes versus monotherapy and justify further research in this area.

\section{Fixed-dose combinations (FDCs)}

FDCs of LAMAs and LABAs offer the potential of improved convenience and compliance over use of separate inhalers, and, during their development, the dose of each agent to be used in combination can be optimized.

A major challenge associated with development of an FDC is provision of improved bronchodilation over monotherapy components while balancing the associated adverse effects [77]. Dose-finding studies are required to establish minimal effective doses for each agent in the combination, as it cannot be assumed that these doses are the same as would be used in monotherapy. Regulatory bodies also require investigation into any pharmacodynamic or pharmacokinetic interactions that may occur between the constituents, along with evidence of the safety profile for the combination $[77,78]$.

A number of FDCs are in development, with substantial clinical programs (Table 4), and some Phase II/III results are available (Table 3). In all cases, there is evidence of improved lung function parameters with the combinations versus monotherapy components. Glycopyrrolate/ glycopyrronium is being developed as part of two combinations: the former plus formoterol as a twice-daily combination (Pearl Therapeutics) and the latter plus indacaterol as a once-daily combination (Novartis). Glycopyrrolate plus formoterol has recently reported improvements in $\mathrm{FEV}_{1}$ area under the curve from $0-12$ hours $\left(\mathrm{AUC}_{0-12}\right)$ versus monotherapy with glycopyrrolate, formoterol, or tiotropium 
Table 3 LABA and LAMA combinations: current evidence

\section{Combination (manufacturer)}

\section{Free combinations}

GSK233705: 20 or 50 mg BID; salmeterol: $50 \mu \mathrm{g}$ BID

Beier et al. [61]

Tiotropium: $18 \mu \mathrm{g}$ QD; arformoterol: $15 \mu \mathrm{g}$ BID

Tiotropium: $18 \mu \mathrm{g}$ QD; formoterol: $20 \mu \mathrm{g}$ BID

Tiotropium: $18 \mu \mathrm{g}$ QD; formoterol: $20 \mu \mathrm{g}$ BID

Tiotropium: $18 \mu \mathrm{g}$ QD; formoterol: $12 \mu \mathrm{g}$ BID

Tiotropium: $18 \mu \mathrm{g}$ QD; formoterol: $12 \mu \mathrm{g}$ QD or BID

Tiotropium: $18 \mu \mathrm{g}$ QD; formoterol: $12 \mu \mathrm{g}$ QD or BID

Tiotropium: $18 \mu \mathrm{g}$ QD; formoterol: $12 \mu \mathrm{g}$ QD or BID

Tiotropium: $18 \mu \mathrm{g}$ QD; formoterol: $10 \mu \mathrm{g}$ BID

Tiotropium: $18 \mu \mathrm{g}$ QD; indacaterol: $150 \mu \mathrm{g}$ QD

Tiotropium: $18 \mu \mathrm{g}$ QD; salmeterol: $50 \mu \mathrm{g}$ BID
Tashkin et al. [60]

Hanania et al. [65]

Tashkin et al. [56]

Tashkin et al. [55]

Terzano et al. [66]

van Noord et al. [47]

van Noord et al. [49]

Vogelmeier et al. [54]

Mahler et al. [50]

Aaron et al. [48]
Larger mean increases from baseline trough $\mathrm{FEV}_{1}$ vs placebo with $20 \mu \mathrm{g}$ GSK233705 + salmeterol (203 mL) and $50 \mu \mathrm{g}$ GSK233705 + salmeterol (215 mL) vs monotherapy with tiotropium $(101 \mathrm{~mL})$ or salmeterol $(118 \mathrm{~mL})$

Greater improvement in $\mathrm{FEV}_{1} \mathrm{AUC}_{0-24}$ from baseline with combination $(0.22 \mathrm{~L})$ vs monotherapy with either arformoterol $(0.10 \mathrm{~L})$ or tiotropium $(0.08 \mathrm{~L}) ; \mathrm{p}<0.001$

Greater improvement in TDI with combination (3.1) vs monotherapy with either arformoterol $(2.3 ; \mathrm{Cl} 0.03,1.70)$ or tiotropium (1.8; Cl 0.50, 2.20)

$\mathrm{FEV}_{1} \mathrm{AUC}_{0-3}$ greater with combination $(1.57 \mathrm{~L})$ vs tiotropium alone $(1.38 \mathrm{~L}) ; \mathrm{p}<0.0001$

Reduced use of rescue medication vs tiotropium alone $p<0.05$

Greater $\mathrm{FEV}_{1} \mathrm{AUC}_{0-3}$ with combination (1.52 L) vs tiotropium alone $(1.34 \mathrm{~L}) ; \mathrm{p}<0.0001$

Greater improvement in TDI with combination than tiotropium alone (2.30 vs 0.16; mean difference of 1.80); $95 \% \mathrm{Cl} 0.86,2.74, \mathrm{p}<0.0002$

Greater improvement in $\mathrm{FEV}_{1} \mathrm{AUC}_{0-4}$ from baseline with combination $(0.34 \mathrm{~L})$ vs tiotropium alone $(0.17 \mathrm{~L}) ; p<0.001$

Dyspnea significantly improved with combination at week 8 (1.86) vs tiotropium alone (1.01); $p=0.013$

Reduced use of rescue medication vs tiotropium alone; $\mathrm{p}<0.04$

Greater improvement in $\mathrm{FEV}_{1}$ with combination vs tiotropium alone at day $30(0.16 \mathrm{~L}) ; p=0.0001$

Improvement in dyspnea with combinations (2.32-2.61) vs tiotropium alone (1.0); $p<0.05$

Lower rescue medication use with combinations (0.71-0.80 puffs/day) vs tiotropium alone (2.14 puffs/day); $p<0.05$

Greater average improvement in $\mathrm{FEV}_{1} \mathrm{AUC}_{0-24}$ 0.16-0.20 L with combinations vs $0.08 \mathrm{~L}$ with tiotropium alone; $\mathrm{p}<0.05$

Lower rescue medication use with combinations vs tiotropium alone; $\mathrm{p}<0.01$ (daily rescue medication use with tiotropium + formoterol QD or BID) and $\mathrm{p}<0.05$ (tiotropium + formoterol BID)

Average improvement in daytime $(0.234 \mathrm{~L})$ and night-time $\mathrm{FEV}_{1}(0.086 \mathrm{~L})$ with combination vs monotherapy with tiotropium $(p \leq 0.001)$ or formoterol $(p \leq 0.01)$

Lower rescue medication use with combination (1.81 puffs/day) vs monotherapies (2.37-2.41 puffs/day); $\mathrm{p}<0.01$

Improvement in $\mathrm{FEV}_{1} 2 \mathrm{~h}$ post-dose after 24 weeks with combination vs formoterol alone $(p=0.044)$

Greater increase in trough $\mathrm{FEV}_{1}$ from baseline with combination: $70-80 \mathrm{~mL}$ difference vs tiotropium alone $(\mathrm{p}<0.001)$

Improved trough IC with combination vs tiotropium alone 100-130 mL; $p<0.01$

Less use of albuterol as rescue medication with combination: reduction of $0.8-1.3$ puffs/day from baseline vs tiotropium alone

No statistical improvement in lung function or hospitalization rates with combination compared to tiotropium monotherapy 
Table 3 LABA and LAMA combinations: current evidence (Continued)

Tiotropium: $18 \mu \mathrm{g}$ QD; salmeterol: $50 \mu \mathrm{g}$ BID

Fixed-dose combinations

Glycopyrrolate: 36 and $72 \mu \mathrm{g}$ BID; formoterol: $9.6 \mu \mathrm{g}$ BID (Pearl Therapeutics)

Glycopyrrolate: 36 and $72 \mu \mathrm{g}$ BID; formoterol: $9.6 \mu \mathrm{g}$ BID (Pearl Therapeutics)

Glycopyrrolate: 36 and $72 \mu \mathrm{g}$ BID; formoterol: $9.6 \mu \mathrm{g} \mathrm{BID}$ (Pearl Therapeutics)

Glycopyrronium: $50 \mu \mathrm{g}$ QD; indacaterol: $300 \mu \mathrm{g}$ QD (Novartis)

Glycopyrronium: $100 \mu \mathrm{g}$ QD; indacaterol: $600 \mu \mathrm{g}$ QD (Novartis)

Glycopyrronium: $50 \mu \mathrm{g}$ QD; indacaterol: $110 \mu \mathrm{g}$ QD (Novartis)

Glycopyrronium: $50 \mu \mathrm{g}$ QD; indacaterol: $110 \mu \mathrm{g}$ QD (Novartis)

Glycopyrronium: $50 \mu \mathrm{g}$ QD; indacaterol: $110 \mu \mathrm{g}$ QD (Novartis)

Tiotropium: $5 \mu \mathrm{g}$ QD; olodaterol: 2, 5, and $10 \mu \mathrm{g}$ QD (Boehringer Ingelheim)

Tiotropium: 1.25, 2.5, and $5 \mu \mathrm{g}$ QD; olodaterol: 5 and $10 \mu \mathrm{g}$ QD (Boehringer Ingelheim)

Umeclidinium (GSK573719): $500 \mu \mathrm{g}$ QD; vilanterol: $25 \mu \mathrm{g}$ QD (GSK) van Noord et al. [59]

Reisner et al. [53]

Reisner et al. [52]

Reisner et al. [62]

van Noord et al. [58]

Van de Maele et al. [57]

Bateman et al. [68]

Vogelmeier et al. [69]

Dahl et al. [67]

Maltais et al. [51]

Aalbers et al. [64]

Feldman et al. [63]
Improved average $\mathrm{FEV}_{1}(0-24 \mathrm{~h})$ with combination $(0.142 \mathrm{~L})$ vs monotherapy with either tiotropium $(0.07 \mathrm{~L})$ or salmeterol $(0.045 \mathrm{~L}) ; \mathrm{p}<0.0001$

Combination associated with clinically relevant improvements in TDI focal score $(p<0.001)$

Increase in $\mathrm{FEV}_{1} \mathrm{AUC}_{0-12}$ on day 7 with combination compared to monotherapy with either of the components, tiotropium, and placebo $(p<0.0001)$

Higher morning pre-trough and peak IC with combination vs placebo ( $p<0.0005$ and $p<0.005$, respectively) or tiotropium monotherapy ( $p<0.05$ for all comparisons)

Similar metabolic and cardiac safety profile to tiotropium

Improved trough $\mathrm{FEV}_{1}$ with combination: $0.226 \mathrm{~L}$ difference in trough $\mathrm{FEV}_{1}$ vs placebo $(p<0.001)$

Greater peak FEV 1 with combination $(1.709 \mathrm{~L})$ vs $300 \mu \mathrm{g}$ indacaterol $(1.579 \mathrm{~L})$ and $600 \mu \mathrm{g}$ indacaterol $(1.573 \mathrm{~L})$; $\mathrm{p}<0.0001$ for both comparisons

Increased trough $\mathrm{FEV}_{1}$ with combination $(1.61 \mathrm{~L})$ vs indacaterol monotherapy $300 \mu \mathrm{g}(1.46 \mathrm{~L}) ; \mathrm{p}<0.05$

Improved trough $\mathrm{FEV}_{1}$ with combination vs placebo $(0.20 \mathrm{~L}$ mean difference), indacaterol $(0.07 \mathrm{~L})$, glycopyrronium $(0.09 \mathrm{~L})$, and tiotropium (0.08 L) monotherapy; $\mathrm{p}<0.001$

Improved TDI score with combination vs placebo (mean difference 1.09); $p<0.001$ and tiotropium (0.51 mean difference); $\mathrm{p}<0.05$

Improved SGRQ score with combination vs tiotropium ( -2.13 mean difference); $p<0.05$

Reduced use of rescue medication with combination vs monotherapies ( -0.30 to -0.54 mean difference); $p<0.05$

Improvement in trough $\mathrm{FEV}_{1}$ with combination vs salmeterol/ fluticasone (mean difference $0.103 \mathrm{~L}$ ); $p<0.0001$

Improvements in TDI score with combination vs salmeterol/ fluticasone (mean difference 0.76); $p=0.003$

Lower use of rescue medication with combination vs salmeterol/fluticasone ( -0.39 puffs/day); $p=0.019$ )

Combination increased $\mathrm{FEV}_{1}$ and FVC vs placebo over a 52-week period; $\mathrm{p}<0.001$

Higher peak $\mathrm{FEV}_{1}$ for all doses of combination investigated vs tiotropium alone $(p \leq 0.05)$; higher trough $F E V_{1}$ response with tiotropium + olodaterol $5 / 10 \mu \mathrm{g}$ vs tiotropium alone $(p=0.034)$

Significant improvements in $\mathrm{FEV}_{1}$ for all doses of combination vs olodaterol alone, with evidence of a dose-dependent response

Adverse-event rate of $26 \%$, with no single adverse event reported in $>1$ patient

Combination similar to placebo in terms of cardiac parameters

Greater change from baseline in trough $\mathrm{FEV}_{1}$ and $\mathrm{FEV}_{1}$ from 0-6 h post-dose with combination vs placebo 
Table 4 LABA and LAMA combinations under investigation: ongoing trials

\begin{tabular}{|c|c|c|c|}
\hline LAMA & LABA & Trial numbers & Summary of ongoing Phase II/III studies \\
\hline um & Formo & $\begin{array}{l}\text { NCT01572792, NCT0143797, } \\
\text { NCT01462942, NCT01437540, } \\
\text { NCT01049360 }\end{array}$ & $\begin{array}{l}4 \text { Phase III studies and } 1 \text { Phase II study, examining the long-term } \\
\text { efficacy and safety of } 2 \text { different doses of aclidinium + formoterol vs } \\
\text { monotherapy with either component and placebo }\end{array}$ \\
\hline lycopyrrolate & Formoterol & NCT01587079, NCT01587079 & $\begin{array}{l}2 \text { Phase II studies (both recently completed), examining efficacy of the } \\
\text { combination vs the monotherapy components and tiotropium }\end{array}$ \\
\hline Glycopyrronium & Indacaterol & $\begin{array}{l}\text { NCT01120691 (SPARK), NCT01202188 } \\
\text { (GLEAM) (pivotal studies, both completed), } \\
\text { NCT0171251, NCT01604278, NCT01727141, } \\
\text { NCT01529632, NCT01709903 }\end{array}$ & $\begin{array}{l}2 \text { recently completed pivotal Phase III studies investigating efficacy and } \\
\text { safety, exacerbations, exercise, and TDI, and } 5 \text { ongoing Phase III studies, } \\
\text { examining safety and efficacy of combination vs placebo, monotherapy } \\
\text { components, and salmeterol/fluticasone }\end{array}$ \\
\hline Tiotropium & Olodaterol & $\begin{array}{l}\text { NCT01431274, NCT01431287 (pivotal studies), } \\
\text { NCT01525615, NCT01533922, NCT01533935, } \\
\text { NCT01559116, NCT01536262 }\end{array}$ & $\begin{array}{l}7 \text { Phase III studies, investigating efficacy and safety of combination vs } \\
\text { monotherapy components and effects on exercise }\end{array}$ \\
\hline $\begin{array}{l}\text { Umeclidinium } \\
\text { (GSK573719) }\end{array}$ & Vilanterol & $\begin{array}{l}\text { NCT01313637, NCT01316900, NCT01316913, } \\
\text { NCT01313650 (pivotal studies, recently } \\
\text { completed), NCT01716520, NCT01491802 }\end{array}$ & $\begin{array}{c}6 \text { Phase III studies (4 recently completed, } 2 \text { ongoing), focused primarily } \\
\text { on efficacy, with other studies examining AE incidence, exercise } \\
\text { endurance time, and exertional dyspnea }\end{array}$ \\
\hline
\end{tabular}

ClinicalTrials.gov was searched for Phase II and III trials of fixed-dose combinations of LAMA + LABA. Access date: 12/05/12.

$\mathrm{LABA}=$ long-acting $\beta_{2}$-agonist; $\mathrm{LAMA}=$ long-acting muscarinic antagonist; $\mathrm{AE}=$ adverse event; $\mathrm{TDI}=$ Transition Dyspnea Index; FDA = Food and Drug Administration.

[52], and in inspiratory capacity versus tiotropium monotherapy [53] (Table 3). Indacaterol is approved at doses of 150 and $300 \mu \mathrm{g}$ in the EU, and $75 \mu \mathrm{g}$ in the US [79]. Early studies investigated high doses of indacaterol in combination with glycopyrronium $[57,58]$, but the recent SHINE, ILLUMINATE, and ENLIGHTEN studies have examined the effects of indacaterol $(110 \mu \mathrm{g})$ plus glycopyrronium $(50 \mu \mathrm{g}$ ) (Table 3 ). The SHINE study reported significantly greater improvements in trough $\mathrm{FEV}_{1}$ after 26 weeks' treatment with the combination compared to monotherapy with indacaterol (mean difference $70 \mathrm{~mL}$ ), glycopyrronium $(90 \mathrm{~mL})$, or tiotropium (80 mL) [68]. This study also demonstrated improvements in dyspnea (versus placebo and tiotropium), St George's Respiratory Questionnaire (versus placebo), and reduced use of rescue medication (versus placebo and all monotherapies). The ILLUMINATE study has provided interesting information on the relative effects on lung function of a LABA/LAMA combination versus LABA/ inhaled corticosteroids (ICS): significant, sustained, and clinically meaningful improvements in trough $\mathrm{FEV}_{1}$, peak $\mathrm{FEV}_{1}$, and $\mathrm{FEV}_{1} \mathrm{AUC}_{0-12}$ with indacaterol plus glycopyrronium versus the LABA/ICS salmeterol/fluticasone ( $p<0.001$ for all comparisons) [69]. Mean treatment difference for indacaterol plus glycopyrronium versus salmeterol/fluticasone ranged from $103 \mathrm{~mL}$ (trough $\mathrm{FEV}_{1}$ ) to $155 \mathrm{~mL}$ (peak $\mathrm{FEV}_{1}$ ) [69]. Additionally, the longer-term ENLIGHTEN study reported significant improvements in lung function with the combination versus placebo sustained for 52 weeks, with no evidence of tachyphylaxis [67].

Clinical Phase II trials have investigated the optimal dosing for olodaterol added to a fixed dose of tiotropium [51] and for tiotropium added to a fixed dose of olodaterol [64]. Significant improvements in peak FEV $_{1}$ were demonstrated with tiotropium/olodaterol $5 / 2 \mu \mathrm{g}$ $(\mathrm{p}=0.008), 5 / 5 \mu \mathrm{g}(\mathrm{p}=0.012)$, and $5 / 10 \mu \mathrm{g}(\mathrm{p}<0.0001)$ versus tiotropium monotherapy [51]. Significant improvements were also seen in trough $\mathrm{FEV}_{1}$ with tiotropium/olodaterol 5/10 $\mu \mathrm{g}$ versus tiotropium monotherapy $(p=0.034)$ [51], and with all doses of the combination tested versus olodaterol monotherapy, with evidence of dose ordering [64] (Table 3).

There is little information available from studies of aclidinium plus formoterol; only initial results of preclinical cardiac safety in beagle dogs have been reported [80].

Of the LAMA/LABA FDCs currently under investigation, tiotropium plus olodaterol, umeclidinium plus vilanterol, aclidinium plus formoterol, and glycopyrronium plus indacaterol have the largest Phase III programs, focusing on efficacy, safety, exacerbations, exercise, and dyspnea (Table 4). The development program for umeclidinium plus vilanterol involves four large pivotal trials, one large safety study, and two studies assessing exercise endurance, with two ongoing trials investigating lung function and efficacy. Phase III studies of glycopyrronium plus indacaterol will compare the combination with a range of comparators, including fluticasone/salmeterol combination and tiotropium, across a variety of end points $\left(\mathrm{FEV}_{1}\right.$, exacerbations, TDI, and safety). The tiotropium plus olodaterol development program includes two main registration trials, three examining exercise and functional capacity, one examining long-term safety, and a comprehensive lung function trial.

Several of the LAMA/LABA FDCs in development will be delivered once daily (such as umeclidinium plus vilanterol and tiotropium plus olodaterol) while others will have twice-daily dosing (e.g., aclidinium plus formoterol). This diversity has the potential to increase the personalization of medication to individual needs; for instance, 
twice-daily combinations could be considered where patients suffer from night-time symptoms [81], while once-daily combinations may be prescribed to improve adherence [82].

\section{Delivery devices}

Inhalation devices are intrinsically linked to the medication they deliver. As such, careful consideration of the most appropriate delivery device is crucial to optimal COPD therapy, along with adequate training and observation of patient technique.

The new devices currently in development for delivery of combination inhaled LAMA/LABAs for COPD fall into three main classes: pressurized metered dose inhalers (pMDIs), dry powder inhalers (DPIs), and a propellant-free Soft Mist ${ }^{\mathrm{Tm}}$ Inhaler (SMI), each with its own advantages and disadvantages (Table 5) [83-93]. Poor inhaler technique is often a main cause of suboptimal COPD management [83]; determining a suitable delivery device that each individual patient will be able to use can help to ensure adequate disease management. For instance, a spacer or holding chamber can be used to improve drug delivery via pMDIs in patients with poor coordination between actuation and inhalation. DPIs were designed to ease operation compared to pMDIs [94]. However, it remains important to provide patient training on the specific DPI, as confusion can arise regarding the differing loading techniques for individual devices (e.g., self-contained reservoirs or blister packs versus capsule insertion). Additionally, a higher inspiratory flow is required to operate this type of inhaler, meaning that it may not be appropriate for patients with very severe COPD $[94,95]$. The increased aerosol production time provided by an SMI (1.5 seconds compared to $<0.5$ seconds for most other inhalers) may be an advantage for patients with low inspiratory capacity or poor timing of inhalation to actuation, although teaching and observing the patient's technique remains important [83].

Non-adherence is a well-documented issue in COPD and is associated with detrimental effects on patient outcomes $[96,97]$. Irrespective of the device type, a single device with once-daily dosing may provide a significant advantage, potentially improving adherence and, therefore, patient outcomes. Adherence is inversely related to the number of medications patients take [96] and both treatment persistence and adherence in patients with COPD have been demonstrated to be lower in multiple longacting inhaler users, compared to single long-acting inhaler users [98]. Additionally, a recent large retrospective study reported that adherence was significantly higher in those who initiated treatment with once-daily dosing versus more frequent dosing [82]. On the other hand, apart from the possible advantage of once- over twice-daily

Table 5 Devices for delivery of combination bronchodilators

\begin{tabular}{|c|c|c|c|c|}
\hline $\begin{array}{l}\text { Type of } \\
\text { delivery } \\
\text { device }\end{array}$ & Description & Advantages & Disadvantages & $\begin{array}{l}\text { Combination } \\
\text { products } \\
\text { in development }\end{array}$ \\
\hline \multirow[t]{3}{*}{$\overline{\mathrm{pMDI}}$} & \multirow{3}{*}{$\begin{array}{l}\text { Drug is dissolved in propellant } \\
\text { (generally HFA). When activated, } \\
\text { a valve system releases a metered } \\
\text { volume of propellant containing } \\
\text { the medication }\end{array}$} & $\begin{array}{l}\text { Can be more cost-effective } \\
\text { than DPIs [84] }\end{array}$ & $\begin{array}{l}\text { Can be difficult to } \\
\text { synchronize actuation } \\
\text { with inhalation }[89,90]\end{array}$ & \multirow[t]{3}{*}{$\begin{array}{l}\text { Pearl inhaler for } \\
\text { glycopyrrolate }+ \\
\text { formoterol (Pearl } \\
\text { Therapeutics) [86] }\end{array}$} \\
\hline & & $\begin{array}{l}\text { High fine-particle fraction, } \\
\text { leading to better peripheral } \\
\text { lung deposition }\end{array}$ & $\begin{array}{l}\text { Evidence suggests fewer } \\
\text { patients use pMDls correctly } \\
\text { without teaching [84] }\end{array}$ & \\
\hline & & $\begin{array}{l}\text { Breath-actuated DPIs require } \\
\text { no hand-lung coordination }\end{array}$ & & \\
\hline \multirow[t]{3}{*}{ DPI } & \multirow[t]{3}{*}{$\begin{array}{l}\text { Drug is delivered in powder form } \\
\text { on inspiration by the patient; } \\
\text { de-aggregation of the powder and } \\
\text { generation of the aerosol provided } \\
\text { by the patient's inspiratory effort }\end{array}$} & $\begin{array}{l}\text { Activated by inhalation, avoiding } \\
\text { synchronization issues [84] }\end{array}$ & $\begin{array}{l}\text { Can be more expensive } \\
\text { vs MDls [84] }\end{array}$ & $\begin{array}{l}\text { Breezhaler }^{\circledast} \text { for } \\
\text { indacaterol + } \\
\text { glycopyrronium } \\
\text { (single-dose, } \\
\text { Novartis) [87] }\end{array}$ \\
\hline & & $\begin{array}{l}\text { Evidence suggests more patients } \\
\text { have an accurate inhaler technique } \\
\text { with DPIs without teaching [84] }\end{array}$ & $\begin{array}{l}\text { Errors in inhaler technique } \\
\text { can still occur [92] }\end{array}$ & $\begin{array}{l}\text { Ellipta }^{\circledR} \text { Vilanterol } \\
\text { (single-dose, GSK) }\end{array}$ \\
\hline & & & & $\begin{array}{l}\text { Pressair }^{\oplus} \text { for aclidinium } \\
\text { (multi-dose, Almirall) [88] }\end{array}$ \\
\hline $\begin{array}{l}\text { Soft Mist } \\
\text { Inhaler }\end{array}$ & $\begin{array}{l}\text { Delivers a metered dose of medication } \\
\text { as a slow-moving "soft mist" through } \\
\text { a unique nozzle system, which should } \\
\text { lead to improved lung and reduced } \\
\text { oropharyngeal deposition vs other } \\
\text { types of inhaler }[85,93]\end{array}$ & $\begin{array}{l}\text { Drug delivery is not dependent on } \\
\text { patient's inspiratory capacity or } \\
\text { inspiratory effort, allowing consistent } \\
\text { deposition regardless of lung function } \\
\text { [85] and higher lung deposition in } \\
\text { patients with poor inhaler technique [91] }\end{array}$ & $\begin{array}{l}\text { Less clinical experience } \\
\text { with this device; more } \\
\text { safety data are required }\end{array}$ & $\begin{array}{l}\text { Respimat }^{\circledR} \text { for tiotropium + } \\
\text { olodaterol (Boehringer } \\
\text { Ingelheim) [85] }\end{array}$ \\
\hline
\end{tabular}


dosing on adherence, a twice-daily preparation has the potential advantage of greater improvement in night-time airflow and symptoms, an issue that has recently been reappraised [81].

\section{Consideration of potential adverse effects of LAMA/LABA combinations}

The safety profiles of both LAMAs and LABAs are well understood. However, when combining two entities, it is important to understand both the similarities and differences in adverse events. Given that both muscarinic antagonists and $\beta_{2}$-agonists can have a detrimental effect on the cardiovascular system $[26,99]$, these adverse events need to be monitored carefully in development programs for combination products. Initial results suggest that the cardiovascular safety profile of glycopyrronium plus indacaterol is similar to placebo, with no clinically significant differences observed versus placebo $[57,68]$, and, to date, no safety concerns have been identified with tiotropium plus olodaterol [51]. Free combinations of LAMA/LABA also seem well tolerated. No differences in blood pressure and pulse rate were observed with tiotropium plus salmeterol versus single-agent therapies [59] and the meta-analysis of tiotropium plus formoterol data reported no differences in cumulative incidence of adverse events for the combination (33.2\%) versus tiotropium alone (36.0\%), stating that drug-related severe adverse events and cardiac effects were relatively rare [74].

\section{Emerging therapeutic approaches}

Triple therapy

Triple therapy with LAMA plus LABA/ICS has also been investigated, demonstrating benefits over monotherapy on lung function [48,100-102]. Additionally, a pilot study of patients with advanced COPD reported that triple therapy combined with pulmonary rehabilitation provided a benefit in terms of lung function [103]. Some reports also suggest that triple therapy can provide additional benefits, such as reduction in exacerbation rate and mortality [104], although a recent systematic review concluded that further, longer-term studies are required to determine the benefits of tiotropium plus LABA and ICS [105], or the additional benefit of ICS on top of LAMA/LABA combinations.

\section{Dual muscarinic antagonist- $\beta 2$-agonists (MABAs)}

Another interesting concept is that of single molecules with muscarinic antagonist- $\beta_{2}$-agonist (MABA) activity. While the prospect of combining muscarinic antagonism and $\beta_{2}$-agonism into one entity is highly attractive, this is a new and challenging area of research [106]. The optimal MABA should be designed to achieve balanced, high potencies at both muscarinic and $\beta_{2}$ receptors, for consistency. The furthest developed MABA is GSK961081, which has demonstrated effective bronchoprotection in vivo as proof of concept (NCT00478738) [106] and is currently in Phase IIb studies. MABAs provide a fixed ratio of muscarinic antagonist and $\beta_{2}$-agonist activity at a cellular level, have a single pharmacokinetic profile, and deliver a fixed ratio of muscarinic antagonist and $\beta_{2}$-agonist to the whole lung, simplifying both combination delivery device and clinical development programs [4,5,107]. These properties suggest that MABAs have the potential to act as a useful platform for triple therapy with an anti-inflammatory agent.

\section{Novel bronchodilators}

A number of new bronchodilators with novel modes of action are currently in early stages of development, including $\mathrm{K}^{+}$channel openers, Rho kinase inhibitors, and analogs of vasoactive intestinal peptide; these have been reviewed more extensively elsewhere [7]. Given the substantial evidence supporting a role of Rho kinase in bronchoconstriction [108], Rho kinase inhibitors such as Y-27632, Y-30141, Y-30694, and fasudil may currently hold the most promise, demonstrating smooth muscle relaxant properties in vitro [7]. Once further evidence of efficacy and safety is available, these newer classes might be used in combination with more conventional bronchodilators, leading to additional therapeutic options and increased potential for individualized medication.

\section{Conclusions}

In summary, there is considerable evidence and guidance to support use of the combination of a LAMA and a LABA in COPD, a number of free LAMA and LABA combinations have been studied, and several LABA/ LAMA FDCs are under development.

Although there is a clear rationale for the use of LAMA and LABA combinations, a recent treatment regimen analysis for patients with COPD (based on prescription and medical claims) suggests that currently this free combination is utilized much less frequently than LAMA monotherapy (tiotropium), LABA/ICS

Table 6 Analysis of medical and prescription claims, May 2011-April 2012 [109]

\begin{tabular}{lccc}
\hline & \multicolumn{3}{c}{ Mean monthly patient volume ${ }^{\mathbf{a}}$} \\
\cline { 2 - 4 } Regimen & Total COPD & COPD only & COPD + asthma \\
\hline Tiotropium monotherapy & 310,423 & 279,530 & 30,893 \\
ICS/LABA & 451,019 & 360,760 & 90,259 \\
LABA + LAMA & 5,888 & 5,479 & 410 \\
Tiotropium + ICS/LABA & 193,137 & 170,063 & 23,074 \\
\hline
\end{tabular}

a Data from IMS Health, LifeLink solutions, calculated from US CMS-1500 medical claims and NCPDP prescription claims during period May 2011-April 2012

COPD = chronic obstructive pulmonary disease; ICS = inhaled corticosteroid LABA = long-acting $\beta_{2}$-agonist; LAMA = long-acting muscarinic antagonist. 
combinations, and the triple combination of LAMA plus LABA/ICS in clinical practice (Table 6). These data show that regardless of the presence or absence of comorbid asthma, LABA/ICS is the most widely used of these regimens, followed by tiotropium monotherapy. Interestingly, triple therapy is already a substantially used therapeutic option (usage approximately 60\% of that of tiotropium monotherapy). LABA/ICS is more frequently used in patients with comorbid asthma and COPD [109]. While this practice is to be expected, it is likely that the perceived overlap between asthma and COPD is exaggerated due to the common misconception that a significant bronchodilator response in patients with COPD implies the coexistence of an asthmatic component.

The very limited clinical use of LAMA/LABA combination therapy indicated by these data is perhaps surprising, given the current evidence base and GOLD guidance. However, the evidence from ongoing programs will be much more substantial and the future availability of LAMA/LABA FDCs should make this therapeutic option more convenient than separate administration by two inhalers (typically with different dosing schedules), currently the only option.

The rising number of both single-agent and combination therapies for COPD increases the number of treatment options, and, hence, makes treatment choice more complex. Further studies should be designed to provide substantial evidence for future guideline recommendations. In particular, investigation into the optimal sequencing of monotherapies and combination bronchodilators would be of use to determine where LAMA/LABA FDC therapy may be positioned in the treatment algorithm for COPD. Furthermore, examination of the benefits of using dual bronchodilation as initial maintenance therapy would be of interest, along with which groups of patients may benefit from this approach.

There is a growing appreciation of the benefits of bronchodilation beyond lung function, such as exacerbations [110], patient-reported outcomes, exercise tolerance [111] and exercise capacity, and daily activities $[16,112]$. Trials of LABA/LAMA FDCs should assess this wider range of outcomes in order to more fully understand the broader benefits of increased bronchodilation on a patient's life as a whole.

\begin{abstract}
Abbreviations
$\mathrm{AUC}_{0-12}$ : Area under the curve from 0-12 hours; COPD: Chronic obstructive pulmonary disease; DPI: Dry powder inhaler; ED: Effective dose; FDC: Fixeddose combination; $\mathrm{FEV}_{1}$ : Forced expiratory volume in 1 second; GOLD: Global initiative for chronic Obstructive Lung Disease; ICS: Inhaled corticosteroid; LABA: Long-acting $\beta_{2}$-agonist; LAMA: Long-acting muscarinic antagonist; MABA: Muscarinic antagonist- $\beta_{2}$-agonist; pMDI: Pressurized metered dose inhaler; SMI: Soft Mist ${ }^{\mathrm{TM}}$ Inhaler; TDI: Transition Dyspnea Index.
\end{abstract}

\section{Competing interests}

DPT has received grant support from Boehringer Ingelheim, Pearl

Therapeutics, Novartis, Forest, and GlaxoSmithKline, speaking fees from
Boehringer Ingelheim, Novartis, and Forest, and undertaken consultancy for Pearl Therapeutics, Novartis, and Theravance.

GTF has received grant support from Boehringer Ingelheim, GlaxoSmithKline, Pearl Therapeutics, Novartis, Forest, and Pfizer, speaking fees from Boehringer Ingelheim, GlaxoSmithKline, Astra Zeneca, Novartis, and Forest, and has acted as an advisor to Boehringer Ingelheim, GlaxoSmithKline, Astra Zeneca, Pearl Therapeutics, Forest, and Novartis.

\section{Authors' contributions}

DPT and GTF were responsible for the concept and design of the paper, preparation and revision of the draft, and take full responsibility for the final version of this manuscript.

\section{Acknowledgments}

The authors take full responsibility for the scope, direction, content of, and editorial decisions relating to, the manuscript, were involved at all stages of development, and have approved the submitted manuscript. Medical writing assistance, supported financially by Boehringer Ingelheim, was provided by Caitlin Watson, PhD, of Complete HealthVizion under the authors' conceptual direction and based on feedback from both authors. Boehringer Ingelheim was given the opportunity to check the data used in the review for factual accuracy only.

\section{Author details}

${ }^{1}$ Department of Medicine, David Geffen School of Medicine at UCLA, 405 Hilgard Avenue, Los Angeles, CA 90095, USA. ² Pulmonary Research Institute of Southeast Michigan, 28815 Eight Mile Road, Suite 103, Livonia, Ml 48152 , USA.

Received: 28 January 2013 Accepted: 24 April 2013

Published: 8 May 2013

\section{References}

1. World Health Organization: World health statistics 2008. http://www.who. int/whosis/whostat/2008/en/index.html.

2. Chapman KR, Mannino DM, Soriano JB, Vermeire PA, Buist AS, Thun MJ, Connell C, Jemal A, Lee TA, Miravitlles M, Aldington S, Beasley R: Epidemiology and costs of chronic obstructive pulmonary disease. Eur Respir J 2006, 27:188-207.

3. National Institutes of Health, National Heart, Lung, and Blood Institute: Morbidity \& Mortality: 2012 Chart Book on Cardiovascular, Lung, and Blood Diseases. http://www.nhlbi.nih.gov/resources/docs/2012_ChartBook.pdf.

4. Cazzola M, Matera MG: Emerging inhaled bronchodilators: an update. Eur Respir J 2009, 34:757-769.

5. Cazzola M, Calzetta L, Matera MG: $\beta_{2}$-adrenoceptor agonists: current and future direction. Br J Pharmacol 2011, 163:4-17.

6. Matera MG, Page CP, Cazzola M: Novel bronchodilators for the treatment of chronic obstructive pulmonary disease. Trends Pharmacol Sci 2011, 32:495-506.

7. Cazzola M, Page CP, Calzetta L, Matera MG: Pharmacology and therapeutics of bronchodilators. Pharmacol Rev 2012, 64:450-504.

8. Cazzola M, Rogliani P, Segreti A, Matera MG: An update on bronchodilators in Phase I and II clinical trials. Expert Opin Investig Drugs 2012, 21:1489-1501.

9. Global initiative for chronic Obstructive Lung Disease: Global strategy for the diagnosis, management, and prevention of chronic obstructive pulmonary disease. Revised 2013. http://www.goldcopd.org/guidelinesglobal-strategy-for-diagnisis-management.pdf.

10. US Food and Drug Administration: FDA approved drug products. Ipratropium. http://www.accessdata.fda.gov/scripts/cder/drugsatfda/index.cfm]

11. Yohannes AM, Willgoss TG, Vestbo J: Tiotropium for treatment of stable COPD: a meta-analysis of clinically relevant outcomes. Respir Care 2011, 56:477-487

12. Tashkin DP, Celli B, Senn S, Burkhart D, Kesten S, Menjoge S, Decramer M, for the UPLIFT Study Investigators: A 4-year trial of tiotropium in chronic obstructive pulmonary disease. N Engl J Med 2008, 359:1543-1554.

13. Dahl R, Greefhorst LAPM, Nowak D, Nonikov V, Byrne AM, Thomson MH, Till D, Della Cioppa G, on behalf of the Formoterol in Chronic Obstructive Pulmonary Disease I (FICOPD I) Study Group: Inhaled formoterol dry powder versus ipratropium bromide in chronic obstructive pulmonary disease. Am J Respir Crit Care Med 2001, 164:778-784. 
14. Cazzola M, Santangelo G, Piccolo A, Salzillo A, Matera MG, D'Amato G, Rossi F: Effect of salmeterol and formoterol in patients with chronic obstructive pulmonary disease. Pulm Pharmacol 1994, 7:103-107.

15. O'Donnell DE, Sciurba F, Celli B, Mahler DA, Webb KA, Kalberg CJ, Knobil K Effect of fluticasone propionate/salmeterol on lung hyperinflation and exercise endurance in COPD. Chest 2006, 130:647-656.

16. O'Donnell DE, Flüge T, Gerken F, Hamilton A, Webb K, Aguilaniu B, Make B, Magnussen $\mathrm{H}$ : Effects of tiotropium on lung hyperinflation, dyspnoea and exercise tolerance in COPD. Eur Respir J 2004, 23:832-840.

17. Aguilaniu B: Impact of bronchodilator therapy on exercise tolerance in COPD. Int J Chron Obstruct Pulmon Dis 2010, 5:57-71.

18. Casaburi R, Briggs DD Jr, Donohue JF, Serby CW, Menjoge SS, Witek TJ Jr, for the US Tiotropium Study Group: The spirometric efficacy of once-daily dosing with tiotropium in stable COPD. A 13-week multicenter trial. Chest 2000, 118:1294-1302.

19. Verkindre C, Fukuchi Y, Flémale A, Takeda A, Overend T, Prasad N, Dolker M: Sustained 24-h efficacy of NVA237, a once-daily long-acting muscarinic antagonist, in COPD patients. Respir Med 2010, 104:1482-1489.

20. Novartis Europharm Limited: SPC. Onbrez Breezhaler 150 and 300 microgram inhalation powder, hard capsules. http://www.medicines.org. uk/EMC/medicine/23260/SPC/Onbrez+Breezhaler+150+and+300 +microgram+inhalation+powder\%2c+hard+capsules/.

21. Novartis Pharmaceutical Corporation: ARCAPTA NEOHALER. Full prescribing information. http://www.accessdata.fda.gov/drugsatfda_docs/ label/2012/022383s0002mg.pdf

22. Moen MD: Indacaterol. In chronic obstructive pulmonary disease. Drugs 2010, 70:2269-2280

23. Kerwin EM, Meli J, Peckitt C, Lassen C, Kramer B, Filcek S: Efficacy and safety of indacaterol $75 \mathrm{~g}$ [sic] once daily in patients with moderate-to -severe COPD [abstract]. Am J Respir Crit Care Med 2011, 183:A1595.

24. van Noord JA, Korducki L, Hamilton A, Koker P: Four weeks once daily treatment with $\mathrm{BI} 1744 \mathrm{CL}$, a novel long-acting $\beta 2$-agonist, is effective in COPD patients [abstract A6183]. Am J Respir Crit Care Med 2009, 179:A6183.

25. Hanania NA, Feldman G, Zachgo W, Shim JJ, Crim C, Sanford L, Lettis S, Barnhart F, Haumann B: Dose-related efficacy of vilanterol trifenatate (VI) in COPD [abstract P1227]. Eur Respir J 2010, 36(Suppl 54):217s.

26. Tashkin DP, Fabbri LM: Long-acting beta-agonists in the management of chronic obstructive pulmonary disease: current and future agents. Respir Res 2010, 11:149.

27. Vestbo J, Vogelmeier C, Creemers J, Falques M, Ribera A, Garcia Gil E: Onset of effect of aclidinium, a novel, long-acting muscarinic antagonist, in patients with COPD. COPD 2010, 7:331-336.

28. Gavaldà A, Miralpeix M, Ramos I, Otal R, Carreño C, Viñals M, Doménech T, Carcasona C, Reyes B, Vilella D, Gras J, Cortijo J, Morcillo E, Llenas J, Ryder H, Beleta J: Characterization of aclidinium bromide, a novel inhaled muscarinic antagonist, with long duration of action and a favorable pharmacological profile. J Pharmacol Exp Ther 2009, 331:740-751.

29. Kerwin E, D'Urzo A, Gelb A, Lakkis H, Garcia Gil E, Caracta C: Twice-daily aclidinium bromide in COPD patients: efficacy and safety results from ACCORD COPD I [abstract P1235]. Eur Respir J 2010, 36(Suppl 54):219s.

30. D'Urzo A, Ferguson GT, van Noord JA, Hirata K, Martin C, Horton R, Lu Y, Banerji D, Overend T: Efficacy and safety of once-daily NVA237 in patients with moderate-to-severe COPD: the GLOW1 trial. Respir Res 2011, 12:156.

31. Orevillo C, St Rose E, Strom S, Fischer T, Golden M, Thomas M, Reisner C: Glycopyrrolate MDI demonstrates comparable efficacy and safety to tiotropium DPI in a randomized, double-blind, placebo-controlled phase 2b study in patients with COPD [abstract P3975]. Eur Respir J 2011, 38(Suppl 55):724s

32. Bateman E, Feldman G, Kilbride S, Brooks J, Mehta R, Harris S, Maden C, Crater G: Efficacy and safety of the long-acting muscarinic antagonist GSK233705 delivered once daily in patients with COPD. Clin Respir J 2012, 6:248-257.

33. Donohue JF, Siler T, Kerwin EM, Williams J, Kianifard F, McBryan D: Efficacy and safety of indacaterol $75 \mu \mathrm{g}$ once daily in patients with moderate-to -severe COPD: pooled analysis of two phase III trials [abstract A2258] Am J Respir Crit Care Med 2012, 185:A2258.

34. Kerwin EM, Hebert J, Pedinoff A, Gallagher N, Martin C, Banerii D, Lu Y, Overend T: NVA237 once daily provides rapid and sustained bronchodilation in COPD patients, with efficacy similar to tiotropium: the GLOW2 trial [abstract]. Am J Respir Crit Care Med 2012, 185:A2920.

35. Cazzola M, Tashkin DP: Combination of formoterol and tiotropium in the treatment of COPD: effects on lung function. COPD 2009, 6:404-415.
36. Cazzola M, Molimard M: The scientific rationale for combining long-acting $\beta_{2}$-agonists and muscarinic antagonists in COPD. Pulm Pharmacol Ther 2010, 23:257-267.

37. Bouyssou T, Schnapp A, Casarosa P, Pieper MP: Addition of the new oncedaily LABA BI 1744 to tiotropium results in superior bronchoprotection in pre-clinical models [abstract A4445]. Am J Respir Crit Care Med 2010, 181:A4445.

38. Bouyssou T, Casarosa P, Pieper M, Schnapp A, Gantner F: Synergistic bronchoprotective activity of the long-acting beta 2-agonist olodaterol with tiotropium (long-acting $\mathrm{M}_{3}$ antagonist) and ciclesonide (inhaled steroid) on the ovalbumin-induced bronchoconstriction in anaesthetized guinea pigs [abstract 3451]. Eur Respir J 2011, 38(Suppl 55):613s.

39. Kume H, Imbe S, Iwanaga T, Tohda Y: Synergistic effects between glycopyrronium bromide and indacaterol on a muscarinic agonist-induced contraction in airway smooth muscle [abstract 4835], Presented at the European Respiratory Society Annual Congress, Vienna, Austria, September 1-5. 2012

40. COMBIVENT Inhalation Solution Study Group: Routine nebulized ipratropium and albuterol together are better than either alone in COPD. Chest 1997, 112:1514-1521.

41. COMBIVENT Inhalation Aerosol Study Group: In chronic obstructive pulmonary disease, a combination of ipratropium and albuterol is more effective than either agent alone. An 85-day multicenter trial. Chest 1994, 105:1411-1419.

42. Guleria R, Behera D, Jindal SK: Comparison of bronchodilatation produced by an anticholinergic (ipratropium bromide), a beta- 2 adrenergic (fenoterol) and their combination in patients with chronic obstructive airway disease. An open trial. J Assoc Physicians India 1991, 39:680-682.

43. ZuWallack R, De Salvo MC, Kaelin T, Bateman ED, Park CS, Abrahams R, Fakih F, Sachs P, Pudi K, Zhao Y, Wood CC, on behalf of the Combivent Respimat ${ }^{\circledR}$ inhaler Study Group: Efficacy and safety of ipratropium bromide/albuterol delivered via Respimat ${ }^{\oplus}$ inhaler versus MDI. Respir Med 2010, 104:1179-1188.

44. Dorinsky PM, Reisner C, Ferguson GT, Menjoge SS, Serby CW, Witek TJ Jr: The combination of ipratropium and albuterol optimizes pulmonary function reversibility testing in patients with COPD. Chest 1999, 115:966-971.

45. Campbell S: For COPD a combination of ipratropium bromide and albuterol sulfate is more effective than albuterol base. Arch Intern Med 1999, 159:156-160.

46. van der Molen T, Cazzola M: Beyond lung function in COPD management: effectiveness of LABA/LAMA combination therapy on patient-centred outcomes. Prim Care Respir J 2012, 21:101-108.

47. van Noord JA, Aumann JL, Janssens E, Verhaert J, Smeets JJ, Mueller A Cornelissen PJG: Effects of tiotropium with and without formoterol on airflow obstruction and resting hyperinflation in patients with COPD. Chest 2006, 129:509-517.

48. Aaron SD, Vandemheen KL, Fergusson D, Maltais F, Bourbeau J, Goldstein R, Balter M, O'Donnell D, Mclvor A, Sharma S, Bishop G, Anthony J, Cowie R, Field S, Hirsch A, Hernandez P, Rivington R, Road J, Hoffstein V, Hodder R, Marciniuk D, McCormack D, Fox G, Cox G, Prins HB, Ford G, Bleskie D, Doucette S, Mayers I, Chapman K, et al: Tiotropium in combination with placebo, salmeterol, or fluticasone-salmeterol for treatment of chronic obstructive pulmonary disease. A randomized trial. Ann Intern Med 2007, 146:545-555.

49. van Noord JA, Aumann J-L, Janssens E, Smeets JJ, Verhaert J, Disse B, Mueller A, Cornelissen PJG: Comparison of tiotropium once daily, formoterol twice daily and both combined once daily in patients with COPD. Eur Respir J 2005, 26:214-222.

50. Mahler DA, D'Urzo A, Peckitt C, Lassen C, Kramer B, Filcek S: Combining once-daily bronchodilators in COPD: indacaterol plus tiotropium versus tiotropium alone [abstract]. Am J Respir Crit Care Med 2011, 183:A1591.

51. Maltais F, Beck E, Webster D, Maleki-Yazdi MR, Seibt J-V, Arnoux A, Hamilton $\mathrm{A}$ : Four weeks once daily treatment with tiotropium + olodaterol $(\mathrm{BI}$ 1744) fixed dose combination compared with tiotropium in COPD patients [abstract 5557]. Eur Respir J 2010, 36(Suppl 54):1014s.

52. Reisner C, St Rose E, Strom S, Fischer T, Golden M, Thomas M, Orevillo C: Fixed combination of glycopyrrolate and formoterol MDI (GFF-MDI) demonstrates superior inspiratory capacity (IC) compared to tiotropium DPI (Tio) following 7 days dosing, in a randomized, double-blind, placebo-controlled phase $2 \mathrm{~b}$ study in patients with COPD [abstract P879]. Eur Respir J 2011, 38(Suppl 55):150s.

53. Reisner C, Fogarty C, Spangenthal S, Dunn L, Kerwin EM, Quinn D, Seale JP, Thomas M, St Rose E, Orevillo CJ: Novel combination of glycopyrrolate and formoterol MDI (GFF-MDI) provides superior bronchodilation compared to its 
components administered alone, tiotropium DPI, and formoterol DPI in a randomized, double-blind, placebo-controlled Phase $2 \mathrm{~b}$ study in patients with COPD [abstract]. Am J Respir Crit Care Med 2011, 183:A6453.

54. Vogelmeier C, Kardos P, Harari S, Gans SJM, Stenglein S, Thirlwell J: Formoterol mono- and combination therapy with tiotropium in patients with COPD: a 6-month study. Respir Med 2008, 102:1511-1520.

55. Tashkin DP, Pearle J, lezzoni D, Varghese ST: Formoterol and tiotropium compared with tiotropium alone for treatment of COPD. COPD 2009, 6:17-25.

56. Tashkin DP, Littner M, Andrews CP, Tomlinson L, Rinehart M, Denis-Mize K: Concomitant treatment with nebulized formoterol and tiotropium in subjects with COPD: a placebo-controlled trial. Respir Med 2008, 102:479-487.

57. Van de Maele B, Fabbri LM, Martin C, Horton R, Dolker M, Overend T: Cardiovascular safety of QVA149, a combination of indacaterol and NVA237, in COPD patients. COPD 2010, 7:418-427.

58. van Noord JA, Buhl R, LaForce C, Martin C, Jones F, Dolker M, Overend T: QVA149 demonstrates superior bronchodilation compared with indacaterol or placebo in patients with chronic obstructive pulmonary disease. Thorax 2010, 65:1086-1091.

59. van Noord JA, Aumann J-L, Janssens E, Smeets JJ, Zaagsma J, Mueller A, Cornelissen PJG: Combining tiotropium and salmeterol in COPD: effects on airflow obstruction and symptoms. Respir Med 2010, 104:995-1004.

60. Tashkin DP, Donohue JF, Mahler DA, Huang H, Goodwin E, Schaefer K, Hanrahan JP, Andrews WT: Effects of arformoterol twice daily, tiotropium once daily, and their combination in patients with COPD. Respir Med 2009, 103:516-524.

61. Beier J, van Noord J, Deans A, Brooks J, Maden C, Baggen S, Mehta R, Cahn A: Safety and efficacy of dual therapy with GSK233705 and salmeterol versus monotherapy with salmeterol, tiotropium, or placebo in a crossover pilot study in partially reversible COPD patients. Int J Chron Obstruct Pulmon Dis 2012, 7:153-164.

62. Reisner C, Fernandez C, Orevillo C, St Rose E, Kollar C: Pearl Therapeutics' combination LAMA/LABA MDI (GFF MDI, PT003) provides comparable metabolic and ECG safety to Spiriva ${ }^{\circledR}$ HandiHaler $^{\circledR}$ and placebo in patients with COPD [abstract]. Am J Respir Crit Care Med 2012, 185:A2925

63. Feldman G, Walker RR, Brooks J, Mehta R, Crater G: Safety and tolerability of the GSK573719/vilanterol combination in patients with COPD [abstract A2938]. Am J Respir Crit Care Med 2012, 185:A2938.

64. Aalbers R, Maleki-Yazdi MR, Hamilton A, Waitere-Wijker S, Pivovarova A Schmidt O, Bjermer L: Dose-finding study for tiotropium and olodaterol when administered in combination via the Respimat ${ }^{\circledR}$ inhaler in patients with COPD, Presented at the European Respiratory Society Annual Congress, Vienna, Austria, September 1-5. [abstract 2882] 2012

65. Hanania NA, Boota A, Kerwin E, Tomlinson L, Denis-Mize K: Efficacy and safety of nebulized formoterol as add-on therapy in COPD patients receiving maintenance tiotropium bromide: results from a 6-week, randomized, placebo-controlled, clinical trial. Drugs 2009, 69:1205-1216.

66. Terzano C, Petroianni A, Conti V, Ceccarelli D, Graziani E, Sanduzzi A, D'Avelli S Rational timing of combination therapy with tiotropium and formoterol in moderate and severe COPD. Respir Med 2008, 102:1701-1707.

67. Dahl R, Chapman K, Rudolf M, Mehta R, Kho P, Alagappan V, Berhane I, Chen H, Banerji D: QVA149 administered once daily provides significant improvements in lung function over 1 year in patients with COPD: the ENLIGHTEN study [abstract 2896], Presented at the European Respiratory Society Annual Congress, Vienna, Austria, September 1-5. 2012.

68. Bateman E, Ferguson GT, Barnes N, Gallagher N, Green Y, Horton R, Henley M, Banerji D: Benefits of dual bronchodilation with QVA149 once daily versus placebo, indacaterol, NVA237 and tiotropium in patients with COPD: the SHINE study [abstract 2810], Presented at the European Respiratory Society Annual Congress, Vienna, Austria, September 1-5. 2012.

69. Vogelmeier CF, Bateman ED, Pallante J, Alagappan VKT, D'Andrea P, Chen H, Banerji D: Efficacy and safety of once-daily QVA149 compared with twice-daily salmeterol-fluticasone in patients with chronic obstructive pulmonary disease (ILLUMINATE): a randomised, double-blind, parallel group study. Lancet Resp Med 2013, 1:51-60.

70. Cazzola M, Di Marco F, Santus P, Boveri B, Verga M, Matera MG, Centanni S: The pharmacodynamic effects of single inhaled doses of formoterol, tiotropium and their combination in patients with COPD. Pulm Pharmacol Ther 2004, 17:35-39.

71. Cazzola M, Noschese P, Salzillo A, De Giglio C, D'Amato G, Matera MG: Bronchodilator response to formoterol after regular tiotropium or to tiotropium after regular formoterol in COPD patients. Respir Med 2005 99:524-528.
72. Di Marco F, Verga M, Santus P, Morelli N, Cazzola M, Centanni S: Effect of formoterol, tiotropium, and their combination in patients with acute exacerbation of chronic obstructive pulmonary disease: a pilot study. Respir Med 2006, 100:1925-1932.

73. Rabe KF, Timmer W, Sagkriotis A, Viel K: Comparison of a combination of tiotropium plus formoterol to salmeterol plus fluticasone in moderate COPD. Chest 2008, 134:255-262.

74. Wang J, Jin D, Zuo P, Wang T, Xu Y, Xiong W: Comparison of tiotropium plus formoterol to tiotropium alone in stable chronic obstructive pulmonary disease: a meta-analysis. Respirology 2011, 16:350-358.

75. Berton DC, Reis M, Siqueira AC, Barroco AC, Takara LS, Bravo DM, Andreoni S, Neder JA: Effects of tiotropium and formoterol on dynamic hyperinflation and exercise endurance in COPD. Respir Med 2010, 104:1288-1296.

76. Cazzola M, Centanni S, Santus P, Verga M, Mondoni M, Di Marco F, Matera MG: The functional impact of adding salmeterol and tiotropium in patients with stable COPD. Respir Med 2004, 98:1214-1221.

77. European Medicines Agency: Guideline on the non-clinical development of fixed combinations of medicinal products. http://www.ema.europa.eu/docs/ en_GB/document_library/Scientific_guideline/2009/10/WC500003976.pdf

78. US Department of Health and Human Services, US Food and Drug Administration, Center for Drug Evaluation and Research (CDER): Guidance for industry. Chronic obstructive pulmonary disease: developing drugs for treatment. Draft guidance. http://www.fda.gov/downloads/Drugs/ GuidanceComplianceRegulatoryInformation/Guidances/ucm071575.pdf.

79. Chowdhury BA, Seymour SM, Michele TM, Durmowicz AG, Liu D, Rosebraugh CJ: The risks and benefits of indacaterol - the FDA's review. N Engl J Med 2011, 365:2247-2249.

80. Gavalda A, Vinyals M, Aubets J, Gras J: Effect of formoterol alone and in combination with aclidinium on electrocardiograms in dogs [abstract 2116], Presented at the European Respiratory Society Annual Congress, Vienna, Austria, September 1-5. 2012

81. Agusti A, Hedner J, Marin JM, Barbé F, Cazzola M, Rennard S: Night-time symptoms: a forgotten dimension of COPD. Eur Respir Rev 2011, 20:183-194.

82. Toy EL, Beaulieu NU, McHale JM, Welland TR, Plauschinat CA, Swensen A, Duh MS: Treatment of COPD: relationships between daily dosing frequency, adherence, resource use, and costs. Respir Med 2011, 105:435-441.

83. Yawn BP, Colice GL, Hodder R: Practical aspects of inhaler use in the management of chronic obstructive pulmonary disease in the primary care setting. Int J Chron Obstruct Pulmon Dis 2012, 7:495-502.

84. Brocklebank D, Ram F, Wright J, Barry P, Cates C, Davies L, Douglas G, Muers $M$, Smith D, White J: Comparison of the effectiveness of inhaler devices in asthma and chronic obstructive airways disease: a systematic review of the literature. Health Technol Assess 2001, 5:1-149.

85. Dalby $R$, Spallek M, Voshaar T: A review of the development of Respimat Soft Mist ${ }^{\text {TM }}$ Inhaler. Int J Pharm 2004, 283:1-9.

86. Lechuga-Ballesteros D, Noga B, Vehring R, Cummings RH, Dwivedi SK: Novel cosuspension metered-dose inhalers for the combination therapy of chronic obstructive pulmonary disease and asthma. Future Med Chem 2011, 3:1703-1718.

87. Pavkov R, Mueller S, Fiebich K, Singh D, Stowasser F, Pignatelli G, Walter B, Ziegler D, Dalvi M, Dederichs J, Rietveld I: Characteristics of a capsule based dry powder inhaler for the delivery of indacaterol. Curr Med Res Opin 2010, 26:2527-2533

88. Chrystyn H, Niederlaender C: The Genuair ${ }^{\circledast}$ inhaler: a novel, multidose dry powder inhaler. Int J Clin Pract 2012, 66:309-317.

89. Larsen JS, Hahn M, Ekholm B, Wick KA: Evaluation of conventional pressand-breathe metered-dose inhaler technique in 501 patients. J Asthma 1994, 31:193-199.

90. Goodman DE, Israel E, Rosenberg M, Johnston R, Weiss ST, Drazen JM: The influence of age, diagnosis, and gender on proper use of metered-dose inhalers. Am J Respir Crit Care Med 1994, 150:1256-1261.

91. Brand P, Hederer B, Austen G, Dewberry H, Meyer T: Higher lung deposition with Respimat ${ }^{\oplus}$ Soft Mist ${ }^{\text {TM }}$ Inhaler than HFA-MDI in COPD patients with poor technique. Int J Chron Obstruct Pulmon Dis 2008, 3:763-770.

92. Lavorini F, Magnan A, Dubus JC, Voshaar T, Corbetta L, Broeders M, Dekhuijzen R, Sanchis J, Viejo JL, Barnes P, Corrigan C, Levy M, Crompton GK: Effect of incorrect use of dry powder inhalers on management of patients with asthma and COPD. Respir Med 2008, 102:593-604.

93. Hochrainer D, Hölz H, Kreher C, Scaffidi L, Spallek M, Wachtel H: Comparison of the aerosol velocity and spray duration of Respimat ${ }^{\circledR}$ Soft Mist ${ }^{\mathrm{TM}}$ Inhaler and pressurized metered dose inhalers. J Aerosol Med 2005, 18:273-282. 
94. Geller DE: Comparing clinical features of the nebulizer, metered-dose inhaler, and dry powder inhaler. Respir Care 2005, 50:1313-1321.

95. Wieshammer S, Dreyhaupt J: Dry powder inhalers: which factors determine the frequency of handling errors? Respiration 2008, 75:18-25.

96. Lareau SC, Yawn BP: Improving adherence with inhaler therapy in COPD. Int I Chron Obstruct Pulmon Dis 2010, 5:401-406.

97. Melani AS, Bonavia M, Cilenti V, Cinti C, Lodi M, Martucci P, Serra M, Scichilone N, Sestini P, Aliani M, Neri M, on behalf of the Gruppo Educazionale Associazione Italiana Pnemologi Ospedalieri (AIPO): Inhaler mishandling remains common in real life and is associated with reduced disease control. Respir Med 2011, 105:930-938.

98. Yu AP, Guérin A, Ponce de Leon D, Ramakrishnan K, Wu EQ, Mocarski M, Blum S, Setyawan J: Therapy persistence and adherence in patients with chronic obstructive pulmonary disease: multiple versus single longacting maintenance inhalers. J Med Econ 2011, 14:486-496.

99. Kesten S, Jara M, Wentworth C, Lanes S: Pooled clinical trial analysis of tiotropium safety. Chest 2006, 130:1695-1703.

100. Jung KS, Park HY, Park SY, Kim SK, Kim Y-K, Shim J-J, Moon HS, Lee KH, Yoo $\mathrm{J}-\mathrm{H}$, Lee SD: Comparison of tiotropium plus fluticasone propionate/ salmeterol with tiotropium in COPD: a randomized controlled study. Respir Med 2012, 106:382-389.

101. Chatterjee A, Shah M, D'Souza AO, Bechtel B, Crater G, Dalal AA: Observational study on the impact of initiating tiotropium alone versus tiotropium with fluticasone propionate/salmeterol combination therapy on outcomes and costs in chronic obstructive pulmonary disease. Respir Res 2012, 13:15.

102. Welte T, Miravitlles M, Hernandez P, Eriksson G, Peterson S, Polanowski T, Kessler R: Efficacy and tolerability of budesonide/formoterol added to tiotropium in patients with chronic obstructive pulmonary disease. Am J Respir Crit Care Med 2009, 180:741-750.

103. Pasqua F, Biscione G, Crigna G, Auciello L, Cazzola M: Combining triple therapy and pulmonary rehabilitation in patients with advanced COPD: a pilot study. Respir Med 2010, 104:412-417.

104. Short PM, Williamson PA, Elder DHJ, Lipworth SIW, Schembri S, Lipworth BJ: The impact of tiotropium on mortality and exacerbations when added to inhaled corticosteroids and long-acting $\beta$-agonist therapy in COPD. Chest 2012, 141:81-86.

105. Karner C, Cates CJ: The effect of adding inhaled corticosteroids to tiotropium and long-acting beta ${ }_{2}$-agonists for chronic obstructive pulmonary disease (Review). Cochrane Database Syst Rev 2011, 9:CD009039.

106. Hughes $A D$, Jones $L H$ : Dual-pharmacology muscarinic antagonist and $\beta_{2}$ agonist molecules for the treatment of chronic obstructive pulmonary disease. Future Med Chem 2011, 3:1585-1605.

107. Steinfeld T, Hughes AD, Klein U, Smith JAM, Mammen M: THRX-198321 is a bifunctional muscarinic receptor antagonist and $\beta_{2}$-adrenoceptor agonist (MABA) that binds in a bimodal and multivalent manner. Mol Pharmacol 2011, 79:389-399.

108. Fernandes LB, Henry PJ, Goldie RG: Rho kinase as a therapeutic target in the treatment of asthma and chronic obstructive pulmonary disease. Ther Adv Respir Dis 2007, 1:25-33.

109. IMS Health, LifeLink Solutions: IMS data 5/2011-4/2012. 2012.

110. Vogelmeier C, Hederer B, Glaab T, Schmidt H, Rutten-van Mölken MPMH, Beeh KM, Rabe KF, Fabbri LM, for the POET-COPD Investigators: Tiotropium versus salmeterol for the prevention of exacerbations of COPD. N Engl $J$ Med 2011, 364:1093-1103.

111. Casaburi R, Kukafka D, Cooper CB, Witek TJ Jr, Kesten S: Improvement in exercise tolerance with the combination of tiotropium and pulmonary rehabilitation in patients with COPD. Chest 2005, 127:809-817.

112. Maltais F, Hamilton A, Marciniuk D, Hernandez P, Sciurba FC, Richter K, Kesten S, O'Donnell D: Improvements in symptom-limited exercise performance over $8 \mathrm{~h}$ with once-daily tiotropium in patients with COPD. Chest 2005, 128:1168-1178.

doi:10.1186/1465-9921-14-49

Cite this article as: Tashkin and Ferguson: Combination bronchodilator therapy in the management of chronic obstructive pulmonary disease. Respiratory Research 2013 14:49.

\section{Submit your next manuscript to BioMed Central and take full advantage of:}

- Convenient online submission

- Thorough peer review

- No space constraints or color figure charges

- Immediate publication on acceptance

- Inclusion in PubMed, CAS, Scopus and Google Scholar

- Research which is freely available for redistribution

Submit your manuscript at www.biomedcentral.com/submit
C) Biomed Central 